\title{
Construction Service Competence Test and Training Center (CSCTTC): Small Business Unit Based on the Potential and Intellectual Creativity of the University
}

\author{
Edy Sriyono, Sardi \\ Department of Civil Engineering \\ Janabadra University \\ Yogyakarta, Indonesia \\ edysriyono@janabadra.ac.id, sardi@janabadra.ac.id
}

\author{
Wika H. Putri \\ Department of Accounting, \\ Janabadra University \\ Yogyakarta, Indonesia \\ wikaharisa@janabadra.ac.id
}

\begin{abstract}
The purpose of this study is to initiate a campusbased business unit are a necessity to support higher education, especially to meet the competency goals of graduates and to be closer to the world of work. However, during the initiation process, the necessity to be in a capitalintensive environment is a problem that is always avoided, even though it is realized that it is impossible to start a business without any capital. To realize this initiation, an approach was carried out by establishing a business incubation. The business incubation program designed by the Ministry of Research, Technology and Higher Education to encourage campus-based business units appears to be operationally able to solve the problem of capital-intensive needs needed to develop campus-based business units. The study result shows that empirically, the existence of initial capital as a driving force for a business unit has a significant effect on the opportunities for the development of the business unit.
\end{abstract}

Keywords-Campus business units; capital intensive; business incubation; construction services

\section{INTRODUCTION}

\section{A. Background}

The demands of the global market for workers who are competent and ready to enter the world of work are currently very urgent. The gap that has so far occurred between the competence of college graduates (fresh graduated) and the competencies demanded by industry and employment must be narrowed by making the competence of graduates as close as possible to industry demand so that they can be well absorbed in their respective fields. Current employers do not want to be burdened with work initiation training in the form of competency enhancement because it takes a lot of time and money. Therefore, in many fields, they prioritize workers who are ready to work as indicated by the possession of a work competency certificate.

Graduate employability and competence development in higher education are the primary focus on managing a university. The role of higher education institutions in promoting the development of competences for employability must be planned carefully because one of the main issues associated with competence development and graduate employability found in the review is related to the mismatch between university graduates' competences and employers' needs. Prior research found that graduate employability and competence development around the world depend on a strong sense of innovation and collaboration practices implemented in higher education[1].

University also often criticized for not preparing graduates for the real contexts involved in their professional practice[2], and it caused the graduate cannot meet the qualification in the job requirement. So, a higher education institution should prepare the primary initiative to solve the problems, and one of the alternatives is making training center which held professional competence training.

In the construction service sector, this need is increasingly real, with the enactment of the Construction Services Law Number 2 of 2017 which in Article 70 states that every construction worker who works in the construction service sector is required to have a work competency certificate [3]. On the other hand, employers in the construction service sector are also obliged to employ workers who have work competency certificates [4]. The mandate of this law clearly and firmly provides a signal, especially for universities as providers of graduates to immediately move and respond proactively to the demands of the world of work.

Changing parameters in higher education by globalization has led to an updating of the global-wide standard and make a new paradigm[5]. The fact that so far there is that universities are in the process of implementing and implementing the KKNI-based competency curriculum (Indonesian National Qualification Framework) as a response to efforts to eliminate the competency gap [6]. Universities have to make a difference and bring additional value to their students to make a competitiveadvantages[7]. While waiting for the process, a breakthrough is needed so that prospective graduates who are currently still carrying out the academic process on campus can jointly and gradually take part in and pass the professional competency test. The current condition in many universities, especially civil engineering graduates, most of them do not have 
certification if they do not independently participate in the competency certification program.

Meanwhile, although the above opportunities are quite large, in the existing conditions, there is not a single university that has officially held a proactive competency certification test preparation program to obtain a certificate of expertise. Generally, this program is held if there is a government program and collaborates with universities and is incidental to adjusting the government's budget line.

Generally, certification of expertise in the field of construction services is only held by the Professional Association and Construction Services Development Agency (CSDA), both central and provincial. In fact, to go to a certification test that aims to obtain a certificate of expertise, graduates need to follow technical guidance and due diligence as a preparation step in order to pass and obtain a certificate of expertise competency. Demand for the university to fulfil requirements of the national academic community the criteria for assessing students' competencies in the context of the formation of functional literacy, the ability to study and evaluate independence, global competence and meta-subject skills (soft skills)[8] are considered to forming the CSCTTC in Janabadra University

The role of the Civil Engineering Study Program, Janabadra University is manifested in the form of establishing a Construction Service Competence Test and Training Center (CSCTTC) which will partner with the Construction Technology Application Center, Director General of Construction Development, Minister for Public Works and Human Settlements, Construction Services Development Board (LPJK) DIY, and the Indonesian Consultants Association (INTAKINDO) DIY. The mission of the CSCTTC is "Increasing the competence of workers in the construction sector and conducting certification by providing training and competency testing through Competency-Based Training (CBT) for construction workers".

The design for preparing competent and certified personnel in this program is without waiting for students to graduate, when they have taken the prerequisite courses for certain competency tests, they can gradually also prepare themselves to take the competency test by following technical guidance and due diligence, outside from the compulsory higher education curriculum. Graphically, the products that will be tried to be offered in this program are as follows:

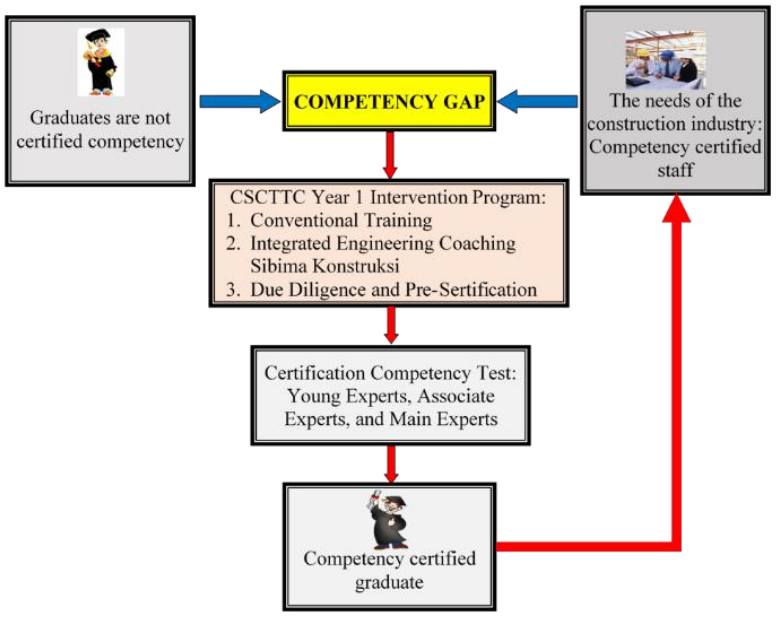

Fig. 1. Position of product market opportunities in existing conditions

\section{B. Product Specifications}

The product to be developed and tried to be offered is a bridging program that aims to narrow the gap between graduate competencies and the competency needs of the labor market and industry. The product form is in the form of training/technical guidance with the aim of preparing students and graduates to achieve competency skills and the second product is a due diligence in the form of a serial test equipped with feedback for program participants, with the aim of testing the output of training/technical guidance as well as efforts to prepare more thoroughly. facing competency certification exam [9], see Table 1.

The target market for this product is students with prerequisites who have taken certain courses or undergraduate/graduate civil engineering who want to enter the construction service industry with the hope that they can achieve certification for young experts.

\section{TABLE 1. CSCTTC PRODUCT SPECIFICATIONS}

\begin{tabular}{|c|c|c|}
\hline Product Name & Specifications & Milestones \\
\hline $\begin{array}{l}\text { Conventional } \\
\text { method training }\end{array}$ & $\begin{array}{l}\text { a. The curriculum is } 50 \text { JPL } \\
\text { face-to-face and } 8 \mathrm{JPL} \text { field } \\
\text { practice } \\
\text { b. Pre-test and post test } \\
\text { c. The training period is } 8 \\
\text { working days }\end{array}$ & $\begin{array}{l}\text { Understand } \\
\text { training materials } \\
\text { to achieve } \\
\text { competency of } \\
\text { young experts }\end{array}$ \\
\hline $\begin{array}{l}\text { Online method } \\
\text { training } \\
\text { integrated with } \\
\text { SIBIMA } \\
\text { KONSTRU-KSI }\end{array}$ & $\begin{array}{l}\text { a. The curriculum is } 50 \mathrm{JPL} \\
\text { online and } 8 \text { JPL field practice } \\
\text { b. Video conference with } \\
\text { instructors while taking online } \\
\text { learning (minimum } 2 \text { times) } \\
\text { c. Pre-test and post test } \\
\text { d. The training period is } 15 \\
\text { working days }\end{array}$ & $\begin{array}{l}\text { Understand } \\
\text { training materials } \\
\text { to achieve } \\
\text { competency of } \\
\text { young experts }\end{array}$ \\
\hline Due Diligence & $\begin{array}{l}\text { a. Serial test which consists of } 5 \\
\text { compulsory exams } \\
\text { b. Participants may take } 5 \text { exams } \\
\text { and must pass } 8 \text { tests } \\
\text { c. Participants are entitled to get } \\
\text { feedback especially on exams } \\
\text { that do not pass }\end{array}$ & $\begin{array}{l}\text { Be thorough in } \\
\text { understanding the } \\
\text { competency test } \\
\text { material and ready } \\
\text { to pass the } \\
\text { competency } \\
\text { certification exam } \\
\text { with a } 75 \% \text { chance } \\
\text { of passing }\end{array}$ \\
\hline
\end{tabular}

While the uniqueness/excellence of the Construction Services Competency Test Training Center (CSCTTC) is that it can create a workforce who has work competence, namely the work ability of each individual which includes 
aspects of knowledge, skills, and work attitudes that are in accordance with the Indonesian National Work Competency Standards (SKKNI) in construction field [6]. This can be done through a process of training and competency testing through Competency Based Training (CBT) in the construction sector [5].

In addition, the Construction Services Competency Test Training Center (CSCTTC) also has the following uniqueness/advantage:

a. The CSCTTC is a training center in the field of construction which was first established in the Special Region of Yogyakarta.

b. The CSCTTC will be an applicable learning medium in applying the Indonesian National Work Competency Standards (SKKNI) in the construction sector.

c. This CSCTTC will also become a Competency Based Training (PBB) media in the field of construction services for workers and prospective workers who come from students of the Civil Engineering Department, graduates of Civil Engineering degrees, and technicians (planners, implementers, and field supervisors).

With the advantages of CSCTTC above, it is hoped that this program will be able to be captured by the market as a form of the bridging program needed by students and graduates of Civil Engineering to get their expertise competency certified.

\section{Objectives}

After the prospective workforce and workers participate in training and competency tests at CSCTTC, the training participants who pass will receive Expertise Certification. Thus, the hope of bringing Civil Engineering graduates closer to the world of work in accordance with the mandate of the Construction Services Law and the Asian Market Agreement (MEA) can be realized immediately by producing workers who have work competence in the construction sector in accordance with the Indonesian National Work Competency Standards (SKKNI)

Meanwhile, economically, this program is a pilot for the realization of business units in universities, especially Janabadra University, where the establishment of CSCTTC will have a positive impact, including honing the ability to manage training programs, involving students and other academics in legal, healthy and independent campus business activities., as well as honing entrepreneurial skills, especially for the Civil Engineering Study Program of the Janabadra University.

\section{METHOD}

\section{A. Customers/Clients}

Types of consumers/clients who will be managed are students of the Civil Engineering Department, construction work technicians (Planners, Implementers, and Supervisors), as well as Civil Engineering graduates.

The condition of existing consumers/clients is that there are still many prospective workers and workers who do not have work competence which is marked by ownership of a certificate of expertise, namely the work ability of each individual which includes aspects of knowledge, skills, and work attitudes in accordance with the Indonesian National Work Competency Standards ( SKKNI).

\section{B. Training Results}

The training results that can be realized from the Construction Service Competence Test and Training Center (CSCTTC) program are:

a. Services for training, due diligence, and competency tests for construction workers

b. Competent workforce products in the construction sector in accordance with the Indonesian National Work Competency Standards (SKKNI).

c. Expertise Certificate for those who have attended Competency Based Training (CBT) and passed the assessment as well as following the Competency Test are declared passed/competent. The expert consists of Young Expert, Associate Expert, and Main Expert.

\section{Training Process}

The training process consists of identification of training needs or Training Needs Assessment (TNA), recruitment and selection of training participants, and implementation of training [10]. There are two approaches that must be taken in the implementation of competencybased training, namely training at SCSTTC (Off the job training) and training in the company/workplace (On the job training).

There are three approaches that can be used by CSCTTC trainers/instructors/facilitators, namely:

a. Learn independently/individually. Independent learning allows trainees to study individually at their own pace. Participants can meet with trainers/instructors at any time to confirm progress and resolve learning difficulties.

b. Study in groups. Group learning allows participants to participate in groups, although the learning process has principles according to everyone's pace. This method allows interaction among participants and trainers/instructors/facilitators.

c. Structured learning. Structured learning is learning in a formal classroom. This method generally covers a specific topic. Structured learning methods can take the form of lectures, pictorial lectures, demonstrations, question and answer, discussion, and practice.

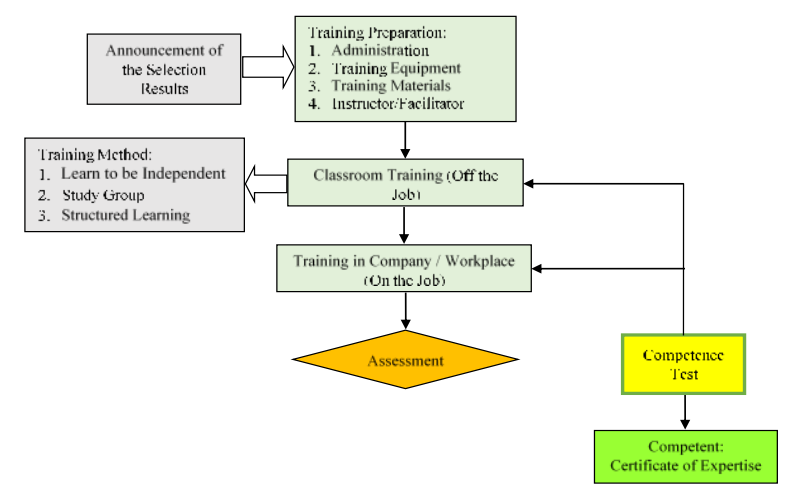


Fig 2. Training Implementation Scheme

Participants who take part in the OJT program at the company/workplace are those who have been declared completed/competent in training at CSCTTC (off the job training). OJT is part of the overall training process carried out in companies/workplaces with a focus on enhancing and strengthening cultural values and work ethic in the company/workplace. OJT must be carried out under the guidance of a companion/employee of the company/workplace (see Figure 2).

\section{RESULTS AND DISCUSSION}

The following are some things related to the management aspects of CSCTTC.

a. Training. The training is carried out in two places, namely: training at CSCTTC (Off the job) and training in the Company/Workplace (On the job)

b. Accounting/bookkeeping, that is carried out by considering all transactions records, the required transaction documents, Janabadra University internal control system, accounting information systems, as well as Janabadra University finance and administration SOP.

c. Audit. The audit was carried out by involving internal auditors from the Janabadra University.

d. Taxation. The taxes that must be paid consist of: income tax, which is charged to clients, VAT, which is charged to clients, and corporate tax, which is charged to CSCTTC.

e. CSCTTC organizational structure. CSCTTC's management structure is in the form of lines and flats, the streamlined structure and flexibility of positions in the organization greatly support cost efficiency and job optimization, which at an early stage still requires large costs. The CSCTTC organizational structure is planned as shown in Figure 3.

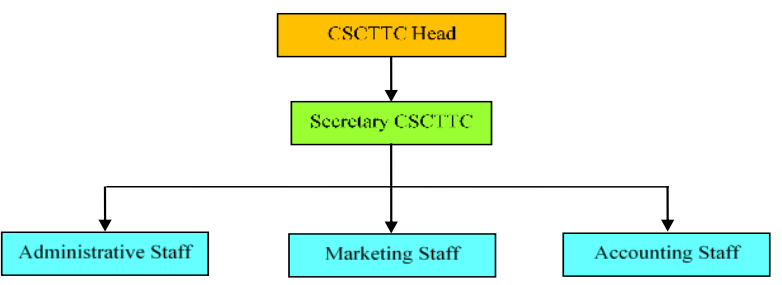

Fig 3.CSCTTC organizational structure

Marketing techniques are carried out by disseminating information on Competency Training and Tests organized by CSCTTC through the CSCTTC Website, Janabadra University Website, Professional Association Website, and Social Media.

Good HR planning is the initial capital for the success of this CSCTTC business. Reliable and professional human resources are the benchmarks for consumers/clients in assessing the image of CSCTTC. High ability and commitment are needed to become CSCTTC's HR. It is estimated that certain qualifications will result in the best training and service to consumers/clients. Details of the number, qualifications and salaries of employees for 1-3 years can be seen in Table II below. Meanwhile, several alternative training cost calculation schemes are shown in Table III.

TABLE II. QUALIFICATIONS,

NUMBERANDSALARYOFEMPLOYEESANDOPPORTUNITIESFOR DEVELOPMENTWITHIN 3 YEARS

\begin{tabular}{|c|c|c|c|}
\hline Qualification & $\begin{array}{c}\text { Number of } \\
\text { employees }\end{array}$ & $\begin{array}{c}\text { Employee } \\
\text { salary/ } \\
\text { month }\end{array}$ & \multicolumn{1}{|c|}{$\begin{array}{l}\text { Development } \\
\text { opportunities }\end{array}$} \\
\hline $\begin{array}{c}\text { Administrative } \\
\text { Staff }\end{array}$ & $\begin{array}{c}\text { 1 person } \\
\text { outsourcing }\end{array}$ & Rp. 1.300.000 & $\begin{array}{l}\text { Training } \\
\text { Customer } \\
\text { Service } \\
\text { Training Public } \\
\text { Relation }\end{array}$ \\
\hline $\begin{array}{c}\text { Marketing } \\
\text { Staff }\end{array}$ & $\begin{array}{l}\text { 1 person } \\
\text { outsourcing }\end{array}$ & Rp. 1.300.000 & $\checkmark \begin{array}{l}\text { Training Visual } \\
\text { Training Public } \\
\text { Relation }\end{array}$ \\
\hline $\begin{array}{c}\text { Accounting } \\
\text { Staff }\end{array}$ & $\begin{array}{c}1 \text { person } \\
\text { outsourcing }\end{array}$ & Rp. 1.300.000 & $\begin{array}{l}\text { Training Display } \\
\text { Training } \\
\text { Customer } \\
\text { Service }\end{array}$ \\
\hline
\end{tabular}

TABLE III. CSCTTC TRAININGCOSTSIMULATION

\begin{tabular}{|c|c|c|c|}
\hline & $\begin{array}{c}\text { Subsidized } \\
\text { Scheme }\end{array}$ & $\begin{array}{c}\text { Independent } \\
\text { Scheme }\end{array}$ & \\
\hline $\begin{array}{c}\text { Fixed costs of } \\
\text { providing training }\end{array}$ & $3,000,000$ & $4,900,000$ & \\
\hline $\begin{array}{l}\text { Variable costs of } \\
\text { providing training }\end{array}$ & $2,570,000$ & $4,500,000$ & \\
\hline Total costs & $5,570,000$ & $9,400,000$ & \\
\hline $\begin{array}{c}\text { COGS for } 10 \\
\text { participants }\end{array}$ & 257,000 & 940,000 & \\
\hline $\begin{array}{c}\text { COGS for } 15 \\
\text { participants }\end{array}$ & 371,333 & 626,667 & \\
\hline $\begin{array}{c}\text { COGS for } 10 \\
\text { participants }\end{array}$ & 278,500 & 470,000 & \\
\hline $\begin{array}{c}\text { Cash Flow } \\
\text { Assumptions } \\
\end{array}$ & $\begin{array}{l}\text { Number of } \\
\text { Participants }\end{array}$ & $\begin{array}{c}\text { Number of } \\
\text { Training }\end{array}$ & Subtotal \\
\hline Revenues at BEP & 10 & 3 & $7,710,000$ \\
\hline positions at & 15 & 3 & $16,710,000$ \\
\hline subsidized rates & 20 & 3 & $16,710,000$ \\
\hline Acceptance of & 10 & 3 & $28,200,000$ \\
\hline BEP positions at & 15 & 3 & $28,200,000$ \\
\hline independent rates & 20 & 3 & $28,200,000$ \\
\hline \multirow{6}{*}{$\begin{array}{l}20 \% \text { profit } \\
\text { assumption }\end{array}$} & 10 & 3 & $9,252,000$ \\
\hline & 15 & 3 & $20,052,000$ \\
\hline & 20 & 3 & $20,052,000$ \\
\hline & 10 & 3 & $33,840,000$ \\
\hline & 15 & 3 & $33,840,000$ \\
\hline & 20 & 3 & $33,840,000$ \\
\hline $\begin{array}{c}\text { Selling Price of } \\
\text { Training Packages }\end{array}$ & 10 & & 308,400 \\
\hline \multirow[t]{2}{*}{$\begin{array}{c}\text { (assumption: all } \\
\text { training package } \\
\text { prices are the } \\
\text { same) }\end{array}$} & 15 & & 445,600 \\
\hline & 20 & & 334,200 \\
\hline
\end{tabular}

The results of the calculation for cash flow for five years can be seen in summary in Table IV below:

TABLE IV. SUMMARYOF CSCTTC CASHFIOW

\begin{tabular}{|c|c|c|c|r|r|}
\hline & Year 1 & Year 2 & Year 3 & Year 4 & Year 5 \\
\hline $\begin{array}{c}\text { Total } \\
\text { investment }\end{array}$ & 240,000 & 240,000 & 240,000 & - & - \\
\hline $\begin{array}{c}\text { Total } \\
\text { revenue }\end{array}$ & 187,650 & 305,000 & 350,000 & 330,000 & 375,000 \\
\hline Total cost & 252,800 & 318,620 & 323,120 & 295,620 & 295,620 \\
\hline $\begin{array}{c}\text { Net cash } \\
\text { flow }\end{array}$ & -65.150 & $-13,620$ & 26,880 & 34,380 & 79,380 \\
\hline
\end{tabular}


*) in thousands Indonesian Rupiah

NPV (assuming 10\% loan interest) is Rp 22,482,608, IRR is $20 \%$, and Payback Period (years) is 5.49. Training activities are feasible to be funded and implemented because NPV $>0$ (positive) and IRR above the assumed interest rate $(10 \%)$, even though the payback period is more than 5 years. Internal Rate of Return (IRR) is a method of calculating investment by calculating an interest rate that equates the present value of an investment with the present value of future net cash receipts. The NPV calculates the estimated future cash flows discounted at the present time. This assumes that the Ministry of Research, Technology and Higher Education's DRPM funds are part of a source of income in the form of subsidies (see Table V).

TABLE V. RESULTAND OUTPUTSFOR SERVICE PRODUCTSAND CONSUMERS YEAR 1

\begin{tabular}{|c|c|c|c|}
\hline Target & Plan & Realization & Information \\
\hline $\begin{array}{l}\text { Number of } \\
\text { participants }\end{array}$ & 25 & Registered 25 & \\
\hline $\begin{array}{l}\text { The number of } \\
\text { participants who } \\
\text { took the } \\
\text { Competency Test }\end{array}$ & 24 & Registered 25 & \\
\hline $\begin{array}{l}\text { The number of } \\
\text { participants who } \\
\text { pass the competency } \\
\text { test and get a } \\
\text { certificate of } \\
\text { expertise }\end{array}$ & $60 \%$ & $\begin{array}{l}\text { Registration for } \\
\text { training and } \\
\text { competency tests } \\
\text { has reached } 50 \%\end{array}$ & $\begin{array}{c}\text { Held on 13-14 } \\
\text { August } 2018 \text { in } \\
\text { collaboration } \\
\text { with } \\
\text { INTAKINDO }\end{array}$ \\
\hline $\begin{array}{l}\text { Evaluation results: } \\
\text { participant feedback }\end{array}$ & $\begin{array}{c}\text { Quite } \\
\text { satisfied }\end{array}$ & $50 \%$ & \\
\hline
\end{tabular}

SIBIMA Construction Distance Learning is very beneficial for fresh graduated or final semester students of S1 / D4 because it is equivalent to $50 \mathrm{JPL}$ online curriculum and 8 JPL field practice or the equivalent of 1year work experience. So those who pass SIBIMA Construction Distance Learning can immediately take the Competency Test and if they pass, they will get a Certificate of Expertise as a Young Construction Expert, so they can save 1 year of work experience.

This CSCTTC program can bring Civil Engineering graduates closer to the world of work in accordance with the mandate of the Construction Services Law and the Asian Market Agreement (MEA), namely by producing workers who have work competence in the construction sector in accordance with the Indonesian National Work Competency Standards (SKKNI).
Economically, this program is a pilot for the realization of business units in universities, especially Janabadra University, where the establishment of CSCTTC will have a positive impact, including honing the ability to manage training programs, involving students and other academics in legal, healthy and campus business activities. independently, and hone entrepreneurial skills, especially for the Civil Engineering Study Program of the Janabadra University.

To sum it up, the Construction Service Competence Test and Training Center (CSCTTC) has proven to be one of the small business units based on the potential and intellectual creativity of the university.

\section{ACKNOWLEDGMENT}

We thank to DRPM, DJPRP, the Ministry of Research, Technology and Higher Education for financial support of this research through their competitive grants scheme.

Thanks for comments and suggestions from reviewers and audiences of The $3^{\text {rd }}$ International Conference on Banking, Accounting, Management, and Economics (ICOBAME) 2020.

\section{REFERENCES}

[1] M. Abelha, S. Fernandes, D. Mesquita, F. Seabra, and A. T. Ferreira-Oliveira, Graduate employability and competence development in higher education-A systematic literature review using PRISMA, Sustain., vol. 12, no. 15, 2020.

[2] P. Knight and M. Yorke, Learning, Curriculum and Employability in Higher Education. Hove, UK: Psychology Press, 2003.

[3] Negara Republik Indonesia, Undang-Undang Republik Indonesia Nomor 2 TentangJasa Konstruksi, 2017.

[4] Negara Republik Indonesia, Undang-Undang Republik Indonesia Nomor 11 TentangKeinsinyuran, 2014.

[5] T. Baaken, B. Kiel, and T. Kliewe, Real World Projects with Companies Supporting Competence Development in Higher Education, Int. J. High. Educ., vol. 4, no. 3, 2015.

[6] Peraturan Menteri Pendidikan Dan Kebudayaan Republik Indonesia Nomor 73Tentang Penerapan Kerangka Kualifikasi Nasional Indonesia Bidang Pendidikan Tinggi, 2013.

[7] M. Salas Velasco, Do higher education institutions make a difference in competence development? A model of competence production at university, High. Educ., vol. 68, no. 4, 2014, pp. 503523.

[8] N. Efremova, O. Shapovalova, and A. Huseynova, Innovative technologies for the formation and assessment of competencies and skills in the XXI century, vol. 18021, 2020.

[9] D. Wira, Analisis Fundamental Saham. Penerbit Exceed, 2011.

[10] Peraturan Menteri Tenaga Kerja dan Transmigrasi Republik Indonesia Nomor 8 Tentang Pedoman Penyelenggaraan Pelatihan berbasis Kompetensi, 2014. 